\title{
Pathogenic Leptospira spp. Seroprevalence and Herd-Level Risk Factors Associated with Chilean Dairy Cattle
}

\author{
Victor Montes ${ }^{1,2}$ and Gustavo Monti ${ }^{3,4, *}$ \\ 1 PhD Program, Faculty of Veterinary Sciences, Universidad Austral de Chile, Valdivia 5090000, Chile; \\ mon_vet77@yahoo.es \\ 2 Department of Veterinary, Faculty of Veterinary Sciences, Universidad Técnica de Manabí, \\ Portoviejo 130701, Ecuador \\ 3 Department of Preventive Veterinary Medicine, Faculty of Veterinary Sciences, Universidad Austral de Chile, \\ Valdivia 5090000, Chile \\ 4 Quantitative Veterinary Epidemiology Group, Wageningen University and Research, \\ 6708 PB Wageningen, The Netherlands \\ * Correspondence: gustavo.monti@wur.nl
}

Citation: Montes, V.; Monti, G Pathogenic Leptospira spp. Seroprevalence and Herd-Level Risk Factors Associated with Chilean Dairy Cattle. Animals 2021, 11, 3148. https://doi.org/10.3390/ani11113148

Academic Editor: Alfonso Zecconi

Received: 6 September 2021

Accepted: 19 October 2021

Published: 4 November 2021

Publisher's Note: MDPI stays neutral with regard to jurisdictional claims in published maps and institutional affiliations.

Copyright: (c) 2021 by the authors. Licensee MDPI, Basel, Switzerland. This article is an open access article distributed under the terms and conditions of the Creative Commons Attribution (CC BY) license (https:/ / creativecommons.org/licenses/by/ $4.0 /)$.
Simple Summary: Leptospirosis is a ubiquitous distributed infectious disease present in wild and domestic animals that can be transmitted to humans. This study aimed to estimate the burden of the bacteria in dairy cows from southern Chile and identify the factors associated with the herd-level status. We studied 147 herds and 4876 lactating cows from the area, and an infected herd was defined when at least one serologically positive reactor to MAT was detected. An epidemiological survey was applied to the herd's owner. The estimated overall individual prevalence was 5.3\% (95\% CI 2.9-7.7), the overall herd-level prevalence was $42.2 \%$ (95\% CI 34.2-50.2), and there was variation in both between different herd sizes. L. borgpetersenii serovars Hardjo and Tarassovi and L. interrogans serovar Pomona were the more frequent serovars in Leptospira non-vaccinated herds. Attenuated Leptospira vaccine usage was assessed as a factor that decreases the risk of a farm being infected $(\mathrm{OR}=0.04 ; 95 \% \mathrm{CI}=0.02-0.11)$, and variables that increase that risk were using bulls for mating $(\mathrm{OR}=3.43 ;(95 \% \mathrm{CI}=1.1-10.1)$ and continuous calving distribution $(\mathrm{OR}=3.4 ; 95 \% \mathrm{CI}=1.3-8.8)$. The results from this study will contribute to unravelling the infection burden in the main dairy area of the country and designing control strategies.

Abstract: Leptospirosis is a ubiquitous distributed zoonotic infectious disease present in wild and domestic animals. This study aimed to estimate within-herd and herd-level seroprevalence against pathogenic Leptospira spp. in dairy cows from southern Chile and identify risk factors associated with the herd-level status. We used a multi-stage strategy combined with a stratified sample strategy for randomly sampling 147 herds and 4876 lactating cows. We considered as infected a herd with at least one positive reactor to MAT. In addition, an epidemiological survey was applied to the herd's owners and a logistic regression (LR) model was constructed to analyze it. The overall within-herd prevalence was 5.9\% (95\% CI 4.9-6.8), the overall herd-level prevalence was $42.2 \%$ (95\% CI 9.2-47.9), and there was variation in both between different herd sizes. L. borgpetersenii serovars Hardjo and Tarassovi and L. interrogans serovar Pomona were the more frequent serovars in nonvaccinated herds. A factor that decreases the risk of a farm being infected was Leptospira vaccine usage $(\mathrm{OR}=0.04 ; 95 \% \mathrm{CI}=0.02-0.11)$, and variables that increase risk were using bulls for mating $(\mathrm{OR}=3.43 ; 95 \% \mathrm{CI}=1.1-10.1)$ and continuous calving distribution $(\mathrm{OR}=3.4 ; 95 \% \mathrm{CI}=1.3-8.8)$. The study's results will contribute to unravelling the infection burden in the main dairy area of the country and designing control strategies.

Keywords: Leptospira; within-herd seroprevalence; herd-level prevalence; risk factors; dairy herds 


\section{Introduction}

Leptospirosis is a globally distributed zoonotic infectious disease that is especially frequent in tropical areas. However, in temperate countries, human cases also occur, though this is frequently incidental, due to travelling abroad to tropical countries or from exposure related to recreational activities [1]. In addition, Leptospirosis has been identified as a re-emerging zoonotic disease affected by global climate change [2,3].

Transmission of pathogenic Leptospira spp. is possible either through direct contact with infected carrier animals or indirectly through contaminated sources, such as water. One relevant source of human infection is rodents [4], but many other wild and domestic animals can be reservoir hosts and shed leptospires [5]. Cattle are one of these species and can be a source of infection and infected cattle could suffer reproductive failure, abortion, stillbirths, fetal mummification, and producing weak calves [6]. Urine from infected cattle can be an infection source for humans, but transmission from cattle to humans is also possible through aborted fetuses or vaginal discharges after abortion or calving [5]; therefore, cattle can pose a possible threat to the health of their owners or persons they are in contact with, such as veterinarians and milkers [7-10].

Serological testing is the most widely used method for diagnosing at herd level, and MAT is the standard serological test [5]. Several serological prevalence studies in cattle at individual or herd level are described, especially in areas where the presentation of Leptospirosis is high. For example, studies estimating individual seroprevalence in Brazilian cattle have reported a seroprevalence of $35.9 \%$ to $61.1 \%$ [11-14] and a herd-level prevalence between $64.8 \%$ and $89.7 \%$ [11-13,15]. In Madagascar, an overall seroprevalence of 59.3\% (95\% CI = 52.0-66.2) was estimated; and in Jordan, an individual seroprevalence of $27.0 \%$ and an overall seroprevalence of $92 \%$ was estimated [16]. In contrast, in temperate countries, such as New Zealand, individual seroprevalence for beef cattle was estimated to be $45.6 \%$ (95\% CI $=43.3-47.9$ ) for L. borgpetersenii serovar Hardjo and $19.6 \%$ (95\% CI $=17.9-21.5)$ for L. interrogans serovar Pomona; herd-level prevalence for Hardjo varied from $79.0 \%$ to $90.5 \%$ and for Pomona from $42.1 \%$ to $68.4 \%$ [17]. In Europe, in Spain, a within-herd seroprevalence of $8 \%$ and a herd-level seroprevalence of $42.2 \%$ was reported [18] and in Ireland, a within-herd seroprevalence of $65.7 \%$ and a herd-level seroprevalence of $91 \%$ was reported [19].

Although in Chile, it has been a notifiable disease in humans since 2001, studies on leptospirosis are scarce [20,21]; it is suspected to be underreported [22], as in many countries. In addition, it is an occupational disease associated with people in contact with animals and poor rural communities [23].

The Chilean cattle stock is approximately 4 million and produces around 2321 million liters of milk per year. Los Lagos and Los Rios regions represent $45 \%$ of this cattle stock and $76 \%$ of the milk production, becoming important regions of meat and milk production in the country [24]. Nevertheless, high abortion rates in these provinces are reported [25], and Leptospirosis is endemic in the country [26].

Chile has reported few, outdated, studies on within-herd or herd-level seroprevalence [21], and the most recently reported study estimated a within-herd seroprevalence ranging from $2 \%$ to $75 \%$, with a median of $15 \%$, and a herd-level prevalence of $75 \%$; however, the study targeted only small farmers [26], nevertheless demonstrating that this infectious agent is present in the environment.

Bovine leptospirosis occurs worldwide and results from infection by a wide variety of serovars [5]. However, the most frequently reported is the L. borgpetersenii serovar Hardjo (Hardjobovis, HB), but L. interrogans serovar Hardjo (Hardjoprajitno, HP) also occurs in cattle in some parts of the world [5]. In Chile, both are present [26-28] in cattle populations.

In the literature, several risk factors have been associated with exposure to pathogenic Leptospira spp. in dairy cattle, such as environmental conditions, management systems, and herd characteristics $[12,13,16,17,29,30]$. In addition, co-grazing with other animals, such as equines, sheep, goats, pigs, deer, or capybaras $[13,17,29,30]$, and grazing in flooded pastures are considered as risk factors [12]. 
This study aimed to estimate within-herd and herd-level seroprevalence against pathogenic Leptospira spp. in dairy cows from southern Chile and identify risk factors associated with the herd-level status. The results from this study will contribute to unravelling the infection burden in the main dairy area of the country.

\section{Materials and Methods}

\subsection{Study Population, Sample Size Estimation, and Selection of Herds}

The study population corresponded to dairy herds located in southern Chile in Los Rios and Los Lagos regions, which are the main dairy production area in the country, holding $44.5 \%$ of the Chilean cattle population [31].

This study was part of a large project that included several pathogens (bovine viral diarrhea virus and Mycobacterium avium subsp. paratuberculosis). A cross-sectional study was performed using a complex survey strategy for accounting for the hierarchical structure of the population (two-stage cluster combined with stratified sampling). Dairy farms were randomly selected from the sampling frame, the Animal Health Services database. The selection was stratified by herd size, defined as small ( $<100$ cows), medium (100-200 cows), and large ( $>200$ cows). The percentage of herds in the sample was proportional to the regional population size $(65 \%, 25 \%$, and $10 \%$, respectively). The eligible population were 150 dairy herds that were randomly selected from Los Ríos and Los Lagos regions. The source population for this study was the 10,859 dairy herds present in both regions [32]; the expected herd prevalence was $50 \%$ (for more conservative sample size), with an accepted error of $8 \%$ and $95 \%$ confidence. The sample was weighted to account for differential sampling probabilities and represent the distribution of the different herd sizes in the region based on [32].

Between July 2011 and August 2012, each herd enrolled in the study was visited by the project's team, and during each visit, all lactating cows were sampled. However, given resource limitations, a random and representative sample of them for each herd was tested and later analyzed, instead of all of them being processed. To estimate the number of samples to be processed for each herd, we considered a simple random sample of a finite population (represented by the number of lactating cows in the herd), with an expected within-herd prevalence of $50 \%$ (the most conservative one for testing proportions), an accepted error of $8 \%$, and a $95 \%$ confidence level. Once we estimated the number of samples to be tested, we selected the cows by a random number generator.

During the visits, 12,311 blood samples were obtained from lactating cows and of these, 4998 samples were finally selected and processed. For estimation of the prevalence of pathogenic Leptospira spp. at the herd level, a herd was considered infected at the herd level if at least one animal with a positive result to microscopic agglutination test (MAT) was found.

Manipulations performed on animals were approved by the Universidad Austral Animal Ethics Committee, protocol 15/2010.

\subsection{Field and Laboratory Procedures}

Five $\mathrm{mL}$ of blood was obtained with vacutainers from the coccygeal vein after disinfection of the area. The samples were kept cold until they were received at the Microbiology laboratory, Universidad Austral de Chile; serum was obtained, and then samples were stored at $-86^{\circ} \mathrm{C}$ until processing.

Serum samples were tested against nine serovars. Panel 1 included the following serovars: L. interrogans serovars Pomona, Canicola, Icterohaemorrhagiae, and Autumnalis and L. borgpetersenii serovars Ballum and Hardjo, which correspond to the most frequent serovars present in South Chile [26]. In addition, another three serovars (L. interrogans serovar Bratislava, L. kirschneri serovar Grippotyphosa, and L. borgpetersenii serovar Tarassovi) were included in panel 2 to broaden the former. MAT was performed as described by Salgado et al. [26], based on the method described by [33]. Nine live antigens were grown in the liquid medium Ellinghausen-McCullough-Johnson-Harris (EMJH), 
and a standardized concentration of $2 \times 10^{8}$ bacteria was used. A positive result was considered when the sample showed $50 \%$ of agglutination for the serovar analyzed.

Currently, in Chile, commercial bacterin vaccines are available that use either a monovalent vaccine with L. borgpetersenii serovariedad Hardjo (Hardjo bovis) (Fortress ${ }^{\circledR}$, Zoetis, NJ, USA), or a pentavalent vaccine with L. interrogans serovars Pomona, Canicola, and Icterohaemorrhagiae; L. kirschneri serovar Grippotyphosa; and L. interrogans serovar Hardjo (Hardjoprajitno) (Cattle master ${ }^{\circledR} 4+$ L5 or Leptoferm5, Zoetis, NJ, USA).

For all serovars, a reciprocal titer of $\geq 1: 200$ was considered positive for animals coming from non-vaccinated herds and $\geq 1: 800$ for vaccinated herds based on two studies that compared antibody responses after vaccination [34,35]. When a sample reacted to more than one serovar, the highest titer was specified as the cause of infection. However, reactions to different serovars at the same titer were considered co-agglutinations. Therefore, an animal was considered as pathogenic Leptospira spp. exposed when showing at least one positive result in any of the serovars included in both panels.

\subsection{Data Analysis}

Fisher's exact test was used to compare proportions between regions of origin, herd size, history, and vaccine use.

Apparent herd prevalence (AHP) was estimated as the number of herds with at least one animal with a MAT-positive result divided by the number of total herds. The apparent individual prevalence (AIP) was estimated using several functions of the package "survey" (V.3.33-2) [36] of the software R (V3.6.3) [37].

\subsection{Risk Factors for Pathogenic Leptospira spp. Herd Status}

A questionnaire (Supplementary Materials) was administered in the enrolled farms to the owner or manager of a farm, followed by a personal interview by a trained veterinarian during blood sampling, to evaluate management practices and herd characteristics associated with the Leptospira herd-infection status under Chilean-pasture-based production and management conditions. The questionnaire was undeclared and pretested for reliability and validity in 10 dairy farms of the area before being applied, checked for question variation, meaning, task difficulty, and respondent interest and attention by the interviewed.

The questionnaire collected data on Leptospira vaccination and deworming protocols, feeding management, semen source, history of abortion, repeat breeders, water source, and availability of veterinary services. Additional details collected included the average size of the milking herd, the number of animals in each age class (calves, heifers, and adult milking cows), the predominant breed of animals in the milking herd, management practices for the different age groups, details of the presence of rats and other domestic animals resident on the property, the presence or absence of biosecurity practices, and whether or not cases of leptospirosis had been diagnosed in cows in the past.

Assessments of the association between potential risk factors and the pathogenic Leptospira spp. herd status were performed using a conditional logistic regression model. The variables were first selected using unconditional logistic regression models with each variable $(p<0.25)$, a conditional model was then constructed using a forward strategy for variable inclusion, and Bayesian's Information Criteria (BIC) were finally used for assessing the goodness-of-fit of the different models. Odds ratios (OR) and their 95\% confidence intervals (CI) for the variables included in the final model were estimated, and a $p$-value of $<0.05$ was used for assigning statistical significance. Additionally, interactions between the variables were evaluated on the basis of biological plausibility and potential confounders. All of the statistical analyses were performed using R V.3.2.2 software [37]. 


\section{Results}

\subsection{Within-Herd Seroprevalence and Herd-Level Prevalence}

A total of 4876 blood samples from the same number of lactating cows were obtained from 150 herds. An overall individual seroprevalence of 5.3\% (95\% CI 2.9-7.7) was estimated; however, the within-herd seroprevalence by herd size was different. The smallest was for large herds $(1.9 \%$; $95 \%$ CI $0.1-3.8)$, followed by the medium-sized herds $(2.8 \%$; $95 \%$ CI 0.01-5.8). The largest was for small herds (11.6\%; 95\% CI 7.3-15.9), and the difference was statistically significant $(p$-value $<0.01$ ).

The estimated overall herd-level prevalence was $42.2 \%$ (95\% CI 34.2-50.2), and there was variation between different herd sizes. For large herds, it was estimated to be $28.6 \%$ (95\% CI 9.2-47.9), for medium-sized herds, it was 22.3\% (95\% CI 7.9-37.3), and for small herds, it was $51.6 \%$ (95\% CI 41.5-61.6).

It was observed that there are a more significant proportion of positive reactors in the Los Rios region $(7.1 \%)$ than in the Los Lagos region $(4.1 \%)(p$-value $<0.05)$.

Non-vaccinated herds presented more significant proportions of reactors $(12.2 \%)$ than vaccinated $(1.1 \%)$, and the difference was statistically significant $(p$-value $<0.01)$.

\subsection{Individual Prevalence by Serovars}

From the serological reactors, $87.4 \%$ seroconverted to serovars included in panel I, $8.4 \%$ to those from panel II, and $4.2 \%$ co-agglutinated. The serovar Hardjo was the most seroconverted in panel I, with $46 \%$, and serovar Tarassovi was the most seroconverted in panel II, with $7.7 \%$ (Table 1 ).

Table 1. Proportion of animals reacting to each serovar included in the MAT panel and prevalence among the dairy cows of southern Chile.

\begin{tabular}{cccccc}
\hline \multirow{2}{*}{ Panel } & \multirow{2}{*}{ Serovar } & \multicolumn{2}{c}{ Seropositive } & \multicolumn{2}{c}{ Prevalence } \\
\cline { 3 - 6 } & & $(\boldsymbol{n})$ & $\mathbf{( \% )}$ & $\mathbf{( \% )}$ & $\mathbf{9 5 \%} \mathbf{C I}$ \\
\hline 1 & $\mathrm{~A}$ & 7 & 2.4 & 0.14 & $0.01-0.30$ \\
1 & $\mathrm{~B}$ & 26 & 9.1 & 0.53 & $0.30-0.80$ \\
1 & $\mathrm{C}$ & 11 & 3.8 & 0.23 & $0.10-0.40$ \\
1 & $\mathrm{H}$ & 132 & 46.1 & 2.71 & $2.30-3.20$ \\
1 & $\mathrm{I}$ & 1 & 0.3 & 0.02 & $0.01-0.10$ \\
1 & $\mathrm{P}$ & 73 & 26.0 & 1.50 & $1.20-1.90$ \\
2 & $\mathrm{Br}$ & 1 & 0.3 & 0.02 & $0.01-0.10$ \\
2 & $\mathrm{G}$ & 1 & 0.3 & 0.02 & $0.01-0.10$ \\
2 & $\mathrm{~T}$ & 22 & 7.7 & 0.45 & $0.30-0.70$ \\
& Coag. & 12 & 4.2 & 0.25 & $0.10-0.40$ \\
\hline & Total & 286 & & 5.87 & $4.9-6.8$ \\
\hline
\end{tabular}

A: Autumnalis; B: Ballum; Br: Bratislava; C: Canicola; G: Grippotyphosa; H: Hardjo; I: Icterohaemorrhagiae,

P: Pomona; T: Tarassovi; Coag: Co-agglutination.

The serovars Autumnalis, Canicola, Pomona, and Hardjo were more reactive in the Los Rios region than in the Los Lagos region, and the difference was statistically significant ( $p$-value $<0.05)$; and serovar Tarassovi was significantly more frequent in the Los Lagos region ( $p$-value $<0.05)$. However, there were no statistically significant differences between the regions for Ballum, Bratislava, Grippotyphosa, and Icterohaemorrhagiae serovars (Table 2).

When evaluating the prevalence of serovars by region, herd size, and Leptospira vaccination history, serovars Hardjo and Pomona were more frequent in the Los Rios region, especially in small herds with no Leptospira vaccination history. In contrast, the serovar Tarassovi was more frequent in the Los Lagos region. In addition, these serovars were constantly observed in non-vaccinated animals. 
Table 2. Frequency of each serovar included in the MAT panel by herd location, herd size, and Leptospira vaccination status of the herd (cut-off titer for non-vaccinated $\geq 1: 200$ and for vaccinated $\geq 1: 800$ ) among the lactating dairy cows of southern Chile $(n=4768)$.

\begin{tabular}{|c|c|c|c|c|c|c|c|c|}
\hline \multirow[b]{2}{*}{ Panel } & \multirow[b]{2}{*}{ Serovar } & \multicolumn{2}{|c|}{ Herd Location $(n)$} & \multicolumn{3}{|c|}{ Herd Size $(n)$} & \multicolumn{2}{|c|}{ Vaccination Status $(n)$} \\
\hline & & $\begin{array}{l}\text { Los Lagos } \\
\text { (1691) }\end{array}$ & $\begin{array}{c}\text { Los Ríos } \\
(3077)\end{array}$ & $\begin{array}{l}\text { Large } \\
(1054)\end{array}$ & $\begin{array}{c}\text { Medium } \\
(1473)\end{array}$ & $\begin{array}{l}\text { Small } \\
(2241)\end{array}$ & $\begin{array}{c}\text { Non-Vaccinated } \\
\text { (2119) }\end{array}$ & $\begin{array}{l}\text { Vaccinated } \\
\quad(2649)\end{array}$ \\
\hline 1 & $\mathrm{~A}$ & 0 & $7 *$ & 0 & 1 & 6 & 7 & 0 \\
\hline 1 & $\mathrm{~B}$ & 6 & 20 & 6 & 1 & $19^{* *}$ & 17 & $9 *$ \\
\hline 1 & $\mathrm{C}$ & 1 & $10 *$ & 1 & 2 & 8 & 10 & $1^{* *}$ \\
\hline 1 & $\mathrm{H}$ & 21 & $111 *$ & 6 & 23 & $103^{* *}$ & 128 & $4^{* *}$ \\
\hline 1 & I & 0 & 1 & 0 & 0 & 1 & 1 & 0 \\
\hline 1 & $\mathrm{P}$ & 12 & $61 *$ & 9 & 8 & $56^{* *}$ & 67 & $6^{* *}$ \\
\hline 2 & $\mathrm{Br}$ & 0 & 1 & 0 & 1 & 0 & 1 & 9 \\
\hline 2 & G & 1 & 0 & 0 & 1 & 0 & 1 & 0 \\
\hline \multirow[t]{3}{*}{2} & $\mathrm{~T}$ & $17^{*}$ & 5 & 2 & 8 & 12 & 17 & $5^{* *}$ \\
\hline & Coag. & 11 & $1^{* *}$ & 1 & 9 & $2 * *$ & 10 & 2 \\
\hline & Total & 69 & 217 & 25 & 54 & $207^{* *}$ & 259 & $27^{* * *}$ \\
\hline
\end{tabular}

A: Autumnalis; B: Ballum; Br: Bratislava; C: Canicola; G: Grippotyphosa; H: Hardjo; I: Icterohaemorrhagiae; P: Pomona; T: Tarassovi; Coag: Co-agglutination. ${ }^{*} p<0.05 ; * * p<0.01$.

The distribution of serovars was also different by herd size, where Hardjo and Pomona serovars were more frequent in the small herds $(p$-value $<0.01)$, whereas serovar Ballum was more frequent in the medium-sized herds than in small or large ones ( $p$-value $<0.01$ ). Conversely, serovars Autumnalis, Canicola, Icterohaemorrhagiae, Bratislava, and Tarassovi were observed in the same proportions in all herd sizes. In addition, it was observed that in the Los Lagos region, the proportion of reactors to serovar Canicola was more frequent in the small herds than in the medium ones ( $p$-value $<0.01)$. Conversely, in the Los Rios region, serovars Hardjo and Pomona were more frequent in small herds ( $p$-value $<0.01)$ and serovar Ballum was more frequent in the medium herd sizes $(p$-value $<0.01)$.

Animals from herds whose owners did not know the background status of pathogenic Leptospira spp. in their farms reacted more frequently to the serovars Canicola, Hardjo, and Tarassovi ( $p$-value $<0.01)$. In contrast, animals from a herd with a known background of a positive diagnosis of pathogenic Leptospira spp. reacted more frequently to serovar Ballum $(p$-value $<0.01)$.

Animals from non-leptospira-vaccinated herds reacted more frequently to serovars Autumnalis, Pomona, Hardjo, and Tarassovi than those from Leptospira-vaccinated herds ( $p$-value $<0.01)$. However, animals from the vaccinated herds reacted more frequently to the serovar Ballum $(p$-value $<0.01)$. In addition, serovars Canicola, Icterohaemorrhagiae, Bratislava, and Grippotyphosa were observed with the same frequency in animals from both non-vaccinated and vaccinated herds.

\subsection{Risk Factors}

\subsubsection{Unconditional Analysis}

Table 3 shows the results obtained from the questionnaire administered to the 147 herds. A total of 27 variables were used for the analysis; of them, 13 variables were selected from the univariate analysis for further analysis: location of the farm (region), herd size, type of dairy farming (only dairy or mixed herd (dairy and beef)), heifer replacement from external sources (yes/no), cow replacement from external sources (yes/no), presence of dogs in the farm, use of a bull for mating (yes/no), use of artificial insemination (yes/no), distribution of calving (seasonal or continuous), use of vaccine against leptospirosis, background of leptospirosis, ever introduced cattle from an external source (yes/no), and regular buying of animals from external sources (open/close). 
Table 3. Prevalence of and risk factors for leptospirosis in South Chile dairy herds.

\begin{tabular}{|c|c|c|c|}
\hline \multirow[t]{2}{*}{ Herd-Level Characteristic } & \multirow[t]{2}{*}{ Category } & \multicolumn{2}{|c|}{$\begin{array}{l}\text { Herd Leptospirosis } \\
\text { Status }\end{array}$} \\
\hline & & Pos. & Neg. \\
\hline \multirow[t]{2}{*}{ Location of the farm (region) } & Los Ríos & 48 & 56 \\
\hline & Los Lagos & 14 & 29 \\
\hline \multirow[t]{3}{*}{ Herd size } & Small & 49 & 46 \\
\hline & Medium & 7 & 24 \\
\hline & Large & 6 & 15 \\
\hline \multirow[t]{2}{*}{ Type of dairy farming } & Dairy only & 48 & 75 \\
\hline & Mixed herd & 14 & 10 \\
\hline \multirow[t]{2}{*}{ Heifer replacement from external sources } & Yes & 14 & 9 \\
\hline & No & 48 & 76 \\
\hline \multirow[t]{2}{*}{ Cow replacement from external sources } & Yes & 48 & 76 \\
\hline & No & 14 & 9 \\
\hline \multirow[t]{2}{*}{ Presence of dogs in the farm } & Yes & 48 & 73 \\
\hline & No & 14 & 12 \\
\hline \multirow[t]{2}{*}{ Use of a bull for mating } & Yes & 52 & 52 \\
\hline & No & 10 & 33 \\
\hline \multirow[t]{2}{*}{ Use of artificial insemination } & Yes & 33 & 55 \\
\hline & No & 29 & 30 \\
\hline \multirow{2}{*}{ Distribution of calving } & Seasonal & 29 & 52 \\
\hline & Continuous & 33 & 33 \\
\hline \multirow[t]{2}{*}{ Use of vaccine against leptospirosis } & Yes & 6 & 61 \\
\hline & No & 56 & 24 \\
\hline \multirow[t]{2}{*}{ Background of leptospirosis } & Yes & 4 & 18 \\
\hline & No & 58 & 67 \\
\hline \multirow{2}{*}{$\begin{array}{l}\text { Ever introduced cattle from an external } \\
\text { source }\end{array}$} & Yes & 22 & 20 \\
\hline & No & 40 & 65 \\
\hline \multirow{2}{*}{$\begin{array}{c}\text { Regular buying of animals from external } \\
\text { sources }\end{array}$} & Open & 41 & 40 \\
\hline & Close & 21 & 45 \\
\hline \multirow{2}{*}{$\begin{array}{c}\text { Regular application of rodent control } \\
\text { measures }\end{array}$} & Yes & 43 & 62 \\
\hline & No & 18 & 22 \\
\hline \multirow[t]{2}{*}{ Regular rodent outbreaks on the farm } & Yes & 33 & 51 \\
\hline & No & 29 & 34 \\
\hline \multirow{2}{*}{$\begin{array}{l}\text { Regular application of ectoparasites control } \\
\text { measures }\end{array}$} & Yes & 60 & 85 \\
\hline & No & 2 & 0 \\
\hline \multirow[t]{2}{*}{$\begin{array}{l}\text { Animals in contact with neighboring } \\
\text { animals via fences }\end{array}$} & Yes & 37 & 48 \\
\hline & No & 25 & 37 \\
\hline \multirow[t]{2}{*}{ Disposal of carcasses within the farm } & Yes & 61 & 82 \\
\hline & No & 1 & 3 \\
\hline Use of feeding yard for heifers & Yes & 59 & 79 \\
\hline & No & 3 & 4 \\
\hline Use of feeding yard for cows & Yes & 55 & 70 \\
\hline & No & 7 & 15 \\
\hline Type of milking & Manual & 8 & 13 \\
\hline & milking machine & 54 & 72 \\
\hline Calf-raising system & with the dam & 22 & 24 \\
\hline Calt-raising system & $\begin{array}{l}\text { Artificial rearing } \\
\text { conditions }\end{array}$ & 40 & 61 \\
\hline Bovines sharing paddocks with other & Yes & 8 & 14 \\
\hline domestic animals (pigs, sheep, horses) & No & 54 & 71 \\
\hline Grouping of cows based on productivity & Yes & 11 & 12 \\
\hline & No & 51 & 73 \\
\hline Paddocks only for heifers & Yes & & \\
\hline
\end{tabular}


Table 3. Cont.

\begin{tabular}{cccc}
\hline Herd-Level Characteristic & Category & \multicolumn{2}{c}{$\begin{array}{c}\text { Herd Leptospirosis } \\
\text { Status }\end{array}$} \\
\hline & & Pos. & Neg. \\
\hline \multirow{2}{*}{ The herd size of the farm (in the last 5 years) } & No & 34 & 37 \\
& Increased & 23 & 35 \\
Presence of wildlife on the farm & Demained stable & 5 & 13 \\
& Decreased & 59 & 83 \\
& Yes & 2 & 2 \\
\hline
\end{tabular}

\subsubsection{Conditional Analysis}

After evaluating interactions and potential confounding factors, Table 4 summarizes the final conditional logistic regression model for factors associated with the leptospirosis status of the farm. The final model contained three variables. All the variables included in the final model were statistically significant, and they are associated with herd management, such as the use of a bull for mating $(\mathrm{OR}=3.43 ; 95 \% \mathrm{CI}=1.1-10.1)$ and increase in the risk of being an infected herd compared to those herds where bulls were not used for mating. In addition, herds with continuous calving along the year have a higher risk of infection $(\mathrm{OR}=3.4 ; 95 \% \mathrm{CI}=1.3-8.8)$ than those with seasonal calving. Finally, the use of leptospirosis vaccines in the herd is a protection factor $(\mathrm{OR}=0.04 ; 95 \% \mathrm{CI}=0.02-0.11)$.

Table 4. Conditional logistic regression model results showing the factors associated with infection by pathogenic Leptospira spp. at the herd level using MAT in herds of southern Chile.

\begin{tabular}{ccccc}
\hline Variable & Category & OR & $\mathbf{9 5 \% ~ C I ~}$ & $p$-Value \\
\hline \multirow{2}{*}{ Use of a bull for mating } & No & Ref. & & \\
& Yes & 3.43 & $1.16-10.14$ & 0.026 \\
Distribution of calving & Seasonal & Ref. & & \\
& Continuous & 3.38 & $1.30-8.79$ & 0.012 \\
Use of vaccine & No & Ref. & & \\
& Yes & 0.04 & $0.02-0.11$ & $<0.01$ \\
\hline
\end{tabular}

\section{Discussion}

This study is the first stratified random survey to investigate the seroprevalence of Leptospira on dairy farms in Chile. On the one hand, the seroprevalence of pathogenic leptospires in lactating cows from dairies in Los Lagos and Los Rios regions was 5.3\%, similar to the $4.3 \%$ reported in Spain [18] but lower to the 55.2\% reported in Paraná and Sao Paulo states, in Brazil [11,15]. On the other hand, the herd-level seroprevalence was $42 \%$, similar to the $43 \%$ reported in Spain for beef and milk herds [18]. In Brazil, larger herd prevalence levels were estimated for Paraná, Sao Paulo, Maranhao, and Paraiba states $(66.6 \%, 70.3 \%, 64.8 \%$, and $89.7 \%$, respectively) $[11,12,38]$. This prevalence is lower than in other countries with more favorable conditions for the maintenance of the bacteria. Environmental factors are relevant aspects to be considered when comparing prevalence between countries as it has been shown that climatic conditions are determinants of infection [5,39], as reflected in the serological response. For example, the prevalence levels were higher in Brazilian studies, in areas with higher-temperature environmental conditions $\left(17-27^{\circ} \mathrm{C}\right)$ and rainfall $(1300-1893 \mathrm{~mm})$. These differences in the prevalence levels, both at the individual level and at the herd level, could partially be explained by the cut-off point (1:100) used to interpret MAT results in Brazil [11-13,15,38], which was lower than the one we used. Another aspect that could explain the difference in the prevalence levels is the number of serovars used in the MAT panel in the different studies, since there could be an increased probability of detecting infected animals at the individual and herd levels if more serovars were included within the diagnostic panel. For example, several 
Brazilian studies used a battery of 22 serovars [11,12,38], compared to the present one, where we used 9. Nonetheless, in our study, adding three serovars to the regular panel resulted in a $0.5 \%$ and $2 \%$ increase in the individual and herd-level prevalence, respectively.

Dairies located in Los Rios region showed the greatest proportion of reactors to pathogenic leptospires compared to those in the Los Lagos region; again, it could be due to many wetlands, which facilitates the survival of Leptospira in the environment. Faine et al. [40] reported that the bacteria could survive in mud, swamps, streams, and rivers. In addition, the region is extensively covered by a cold rainforest, which shelters a varied number of wild species that serve as maintenance hosts of the bacteria [41].

The most significant prevalence was observed on small farms (11.6\%), which could be a consequence of the lower use of vaccines in their prevention schemes. Our results agree with those reported in the same area by [26], where only $4.3 \%$ of small dairies used vaccines against pathogenic Leptospira spp. However, in Chilean production conditions, smallholders also adopted fewer management practices, such as biosecurity measures and regular rodent control, increasing the risk of infection among the animals in their farms [42].

The most reactive serovar was L. borgpetersenii serovar Hardjo, which is not surprising as it is a common finding in other studies $[6,14,16,43]$. For example, Adler and de la Peña-Moctezuma [6] considered this serovar adapted to the bovine species, serving as a maintenance host for this pathogen, which explains its wide spread. In addition, L. borgpetersenii serovar Hardjo is not a significant cause of abortions [44]. Moreover, it appears that L. borgpetersenii serovar Hardjo is less pathogenic than L. interrogans serovar Hardjo (subtype Hardjoprajitno), which could be the reason abortions and fertility issues are more often described in the UK [45] and Australian dairies [46] and for mortality in calves [27]. Another study in the same area in Chile reported a large proportion of reactors (81\%) for the serovar Hardjo as the most frequent [26]; however, the study included only small dairy farms. In addition, isolation has confirmed the presence of both serovars (Hardjobovis and Hardjoprajitno) in the area $[27,28]$. However, given the serovar in MAT is not capable of distinguishing among all these types, the relative frequency of each of them remains unclear. Nevertheless, our results suggest the endemic character of all Hardjo subtypes in dairy cattle in southern Chile.

L. interrogans serovar Pomona was the second serovar in importance. Faine et al. [40] considered serovars Pomona and Hardjo responsible for chronic disease conditions associated with fetal infections and births of premature and weak calves. L. interrogans serovar Pomona incidentally affects cattle, causing acute clinical cases. Faine et al. [40] reported their presence in sheep, goats, and pigs, while the results in this work found no statistical association when cattle co-grazed with these animal species. However, wildlife maintenance hosts such as rodents could carry this pathogen and explain the high frequency. Luna et al. [4] demonstrated L. interrogans serovar Pomona in wild rodents (Abrothrix olivaceus) in $64.3 \%$ of the reactors, captured from 11 dairy herds in southern Chile. It would suggest that these rodents contribute to the maintenance of this serovar in the environment, contaminating spaces where cattle pass or graze.

L. interrogans serovars Hardjo and Pomona were the most prevalent serovars in the present study, and both were more frequent within the Los Rios region among animals from Leptospira non-vaccinated farms, and both are included in commercial vaccines available in the country. However, this evidence was inconclusive that Leptospira vaccination practices on Chilean dairy farms were protective for L. interrogans serovars Hardjo and Pomona. In the present study, only a serological test was used, and, for example, testing the presence of the bacteria in urine was not included. Previous work suggests that microscopic agglutination test (MAT) results after vaccination are weak and of shorter duration, whereas titers to natural infection are stronger and persist for longer [35,47]. It is difficult to use a MAT result to distinguish between Leptospira-vaccinated and naturally exposed cattle because vaccinated cattle subsequently exposed to the live organism can have a strong antibody response despite being protected. In our study, $56 \%$ of the animals belonged to 
farms with a history of vaccination against leptospirosis; therefore, we followed OIE's recommendations to interpret MAT in animals with a history of Leptospira vaccination. Thus, we used a more conservative cut-off point than other studies to reduce the effect of post-vaccination antibodies on the interpretation of the MAT results.

L. borgpetersenii serovar Tarassovi was another serovar with a significant distribution. Although its prevalence was low, it was present in small non-leptospira-vaccinated farms. In Brazil, Hashimoto et al. [15] reported it as the second in importance in the State of Paraná, and in New Zealand, Yupiana et al. [48] reported it as the third in importance. Besides, Faine et al. [40] identified L. borgpetersenii serovar Tarassovi as an adapted and common serovar in pigs. It agrees with the report by [49]. In this study, it was isolated from pig kidneys in slaughterhouses in Valdivia. In addition, this serovar was present in other animal species, for instance, in wild murine rodents, as reported by [41]. In New Zealand, it has been reported as an emerging serovar [7] and still poses a public health risk, especially for farmers. This serovar is not included in the commercial vaccines used in the country and is not usually included in the MAT panel; therefore, the results of this study urge us to consider this to take control measures either for animals and humans.

L. borgpetersenii serovar Ballum was also present in the dairies in southern Chile, with a prevalence of $0.54 \%$, and it was more frequently in non-leptospira-vaccinated farms. Several studies $[6,50,51]$ attribute the persistence of Ballum in the environment to Mus musculus mice, which serve as hosts and are a relevant source of infection to cattle.

Plunkett et al. [52] stated that the antibodies found in Leptospira-vaccinated cattle are specific for serovars included in the vaccine. Therefore, it is a reason to think that serovars Ballum and Tarassovi reported in this study could be generating infection and circulating among the vaccinated animals of these two regions since they are not included in the commercial vaccines used in the country. For this reason, it is of enormous necessity to use other diagnostic tools that allow us to know better the status of infection in the Chilean cattle population. Contrastingly, the mechanisms of antibody production generated by Leptospira vaccines with multiples serovars or if there is a cross response to serovars within each serogroup is not yet evident [53]. Furthermore, studies of vaccine efficacy against other serovars not included in the vaccine are rarely carried out, so their absolute protection is unknown. Therefore, annual Leptospira vaccinations are recommended due to the temporary and limited immunity they generate in cattle [53].

Contrasting results were reported on the relation between antibodies against MAT and elimination of the bacteria via urine. Leonard et al. [54] suggested that antibodies are related to eliminating Leptospira by urine in experimentally infected animals. However, [55] observed urine shedding in animals with antibodies and with titers of $<1: 100$ identified with MAT, indicating an inverse correlation between the presence of antibodies in blood and urine. Gerritsen et al. [56] stated that the immune response does not indicate an animal is shedding the bacteria in the urine. These findings are mainly reported in a chronic state of the disease, when the bacteria reach specific target organs that allow them to be maintained for later elimination [57]. It means that seroprevalence studies are limited when detecting the true animal status, focusing solely on the determination of circulating serogroups within a population [58]. To confirm the status of the animals, the studies require confirmation employing isolates, which can be $50 \%$ different from those found by serological means [59].

On average, sera show a seropositive reaction to one serogroup with a maximum of four. Certainly, MAT is a complex test to control, perform, and interpret given the high degree of cross reaction between different serogroups, especially in acute-phase samples [60]. However, an average of one serogroup per sample was similar to other studies, suggesting a significant proportion of the reactors were in a more chronic phase or just exposed [58].

Among the potential risk factors associated with a herd with at least one positive reactor, the use of bulls was identified as a risk factor associated with herds infected with pathogenic Leptospira spp. Similar results were found by [11] in Sao Paulo and Laos [43]. 
Nevertheless, the role of the bull in disseminating the bacteria is still controversial since it has not been possible to demonstrate the presence of Leptospira in semen samples from animals with MAT-positive titers [61]. Furthermore, in dairy herds from southern Chile, bulls are mainly used to improve reproductive efficiency by improving heat detection and mating repeated cows; therefore, they could spread the bacteria to susceptible cows.

Another factor associated with the status of infection at the herd level was the distribution of calving, where the farms that have non-seasonal calving (continuous throughout the year) had a greater risk of having at least one reactor to pathogenic Leptospira spp. compared to herds with seasonal calving (spring and autumn). This higher risk could be related to a larger accumulation of water in the wintertime, contributing to greater exposure of susceptible animals during the rainy season, which coincides with the calving time. For example, a study in New Zealand demonstrated a more significant number of cases of Leptospirosis in winter and early spring, when young animals come into contact with adults disseminating infection and where humidity conditions are considerably high [62]. In addition, in Scotland, an increase in abortions caused by the serovar Hebdomadis was observed during the autumn and winter seasons (October-January), coinciding with more rainfall and environmental humidity [63]. These environmental factors may increase the risk of infection because animals have more contact with flood areas and water contaminated with urine from the host reservoirs of the infection. In the same way, a source of pollution could be represented by the rodent dejections that invade the barns during the winter, looking for heat and shelter.

The usage of vaccines against Leptospira $(\mathrm{OR}=0.04)$ was associated with a lower risk that a herd has at least one reactor than a herd that was not vaccinate. This is in contrast to what was reported in beef cattle in New Zealand, where Leptospira vaccination was a predisposing risk factor to seroconvert to serovar Hardjo and Pomona [17], and another study of small herds in southern Chile [26], where the usage of vaccines against Leptospira increased the risk of seropositivity to Leptospira. However, the different criteria used to estimate the risk factor concerning the model used and the individual cut-off point of the diagnostic test to define the herd as positive are debatable.

Risk factors reported in other studies, such as co-grazing with other animal species (domestic and wild) $[12,13,29,30]$, were statistically not significant in our study because $84 \%$ of the farmers reported that their cattle co-grazed with domestic species and $97 \%$ reported co-grazing with wild species; therefore, there was a slight chance to detect such a difference in these settings.

\section{Conclusions}

Leptospira are present in South Chile dairy herds and remain a risk to herd managers, their families, and employees. We estimated that in the study area, the seroprevalence of the nine pathogenic Leptospira spp. serovars considered was moderate to high at the herd level but low at the individual animal level in lactating dairy cows. Different frequencies of serovars are present in lactating dairy cows that are not immunized compared to those that have received immunization against Leptospira. Some reproductive management practices that we came across during our study were related to the chance of a herd having at least one reactor animal against pathogenic Leptospira spp.

Supplementary Materials: The following are available online at https:/ / www.mdpi.com/article/10 $.3390 /$ ani11113148/s1, Questionnaire.

Author Contributions: Conceptualization, G.M.; methodology, G.M.; software, G.M.; validation, V.M.; formal analysis, V.M.; resources, G.M.; data curation, V.M.; writing—original draft and preparation, V.M.; writing-review and editing, G.M.; supervision, G.M.; project administration, G.M.; funding acquisition, G.M. All authors have read and agreed to the published version of the manuscript.

Funding: This research was funded by the National Agency of Research and Development (ANID) (grant FONDECYT \#1101020) and the SENESCYT scholarship from the Ecuadorian Government and the Universidad Técnica de Manabí Ecuador. 
Institutional Review Board Statement: The study was conducted according to the guidelines of the Declaration of Helsinki and approved by the Institutional Review Board of Universidad Austral Animal Ethics Committee (15/2010).

Informed Consent Statement: Not applicable.

Data Availability Statement: The data presented in this study are available on request from the corresponding author. However, the data are not publicly available due to the confidentially of the farmers' information.

Acknowledgments: We acknowledge those farmers and veterinarians that participated in the study and allowed us to use their facilities, animals, and personnel for the support and activities related to the study.

Conflicts of Interest: The authors declare no conflict of interest. The funders had no role in the design of the study; in the collection, analyses, or interpretation of data; in the writing of the manuscript; or in the decision to publish the results.

\section{References}

1. Jansen, A.; Schöneberg, I.; Frank, C.; Alpers, K.; Schneider, T.; Stark, K. Leptospirosis in Germany, 1962-2003. Emerg. Infect. Dis. 2005, 11, 1048-1054. [CrossRef]

2. Senior, K. Climate change and infectious disease: A dangerous liaison. Lancet Infect. Dis. 2008, 8, 92-93. [CrossRef]

3. Farrugia, J.; Farrugia, Y.; Vella, C.; Azzopardi, C.M. Emerging infectious diseases and the effect of climate change. Malta Med. J. 2018, 30, 1-4.

4. Luna, J.; Salgado, M.; Tejeda, C.; Moroni, M.; Monti, G. Assessment of Risk Factors in Synanthropic and Wild Rodents Infected by Pathogenic Leptospira spp. Captured in Southern Chile. Animals 2020, 10, 2133. [CrossRef] [PubMed]

5. $\quad$ Ellis, W.A. Animal Leptospirosis. In Leptospira and Leptospirosis; Adler, B., Ed.; Springer: Berlin/Heidelberg, Germany, 2015; Volume 387, pp. 99-137.

6. Adler, B.; de la Peña Moctezuma, A. Leptospira and leptospirosis. Vet. Microbiol. 2010, 140, 287-296. [CrossRef] [PubMed]

7. Yupiana, Y.; Vallee, E.; Wilson, P.; Collins-Emerson, J.; Weston, J.; Benschop, J.; Heuer, C. Emerging Leptospira strain poses public health risk for dairy farmers in New Zealand. Prev. Vet. Med. 2019, 170, 8. [CrossRef] [PubMed]

8. Daud, A.B.; Fuzi, N.; Mohammad, W.; Amran, F.; Ismail, N.; Arshad, M.M.; Kamarudin, S. Leptospirosis and Workplace Environmental Risk Factors among Cattle Farmers in Northeastern Malaysia. Int. J. Occup. Environ. Med. 2018, 9, 88-96. [CrossRef]

9. Cook, E.A.J.; de Glanville, W.A.; Thomas, L.F.; Kariuki, S.; Bronsvoort, B.M.D.; Fevre, E.M. Risk factors for leptospirosis seropositivity in slaughterhouse workers in western Kenya. Occup. Environ. Med. 2017, 74, 357-365. [CrossRef]

10. Sanhueza, J.M.; Heuer, C.; Wilson, P.R.; Benschop, J.; Collins-Emerson, J.M. Prevalence and risk factors for Leptospira exposure in New Zealand veterinarians. Epidemiol. Infect. 2015, 143, 2116-2125. [CrossRef]

11. Castro, V.; Azevedo, S.S.; Gotti, T.B.; Batista, C.S.A.; Gentili, J.; Morais, Z.M.; Vasconcellos, S.A.; Genovez, M.E. Fatores de risco para a leptospirose em fêmeas bovinas em idade reprodutiva no Estado de São Paulo. Arq. Bras. Med. Vet. Zoo 2009, 61, 1438-1442. [CrossRef]

12. Pimenta, C.L.R.M.; Castro, V.; Clementino, I.J.; Alves, C.J.; Fernandes, L.G.; Brasil, A.W.L.; Santos, C.S.A.B.; Azevedo, S.S. Bovine leptospirosis in Para ba State: Prevalence and risk factors associated with the occurrence of positive herds. Pesq. Vet. Bras. 2014, 34, 332-336. [CrossRef]

13. Silva, F.J.; Conceicao, W.L.F.; Fagliari, J.J.; Girio, R.J.S.; Dias, R.A.; Borba, M.R.; Mathias, L.A. Prevalence and risk factors of bovine leptospirosis in the State of Maranhao, Brazil. Pesq. Vet. Bras. 2012, 32, 303-312. [CrossRef]

14. Campos, A.P.; Miranda, D.F.H.; Rodrigues, H.W.S.; Lustosa, M.D.C.; Martins, G.H.C.; Mineiro, A.; Castro, V.; Azevedo, S.S.; Silva, S. Seroprevalence and risk factors for leptospirosis in cattle, sheep, and goats at consorted rearing from the State of Piaui, northeastern Brazil. Trop. Anim. Health Prod. 2017, 49, 899-907. [CrossRef]

15. Hashimoto, V.Y.; Dias, J.A.; Chideroli, R.T.; Barbara, J.C.A.; Brunharo, T.B.; Dutra, L.H.; Silva, M.D.P.; Muller, E.E.; de Freitas, J.C. Epidemiological status of bovine leptospirosis in the State of Parana, Brazil. Semin.-Ciências Agrárias 2015, 36, 4341-4355. [CrossRef]

16. Ismail, Z.B.; Abutarbush, S.M.; Al-Majali, A.; Gharaibeh, M.H.; Al-Khateeb, B. Seroprevalence and risk factors of Leptospira serovar Pomona and Leptospira serovar Hardjo infection in dairy cows in Jordan. J. Infect. Dev. Ctries. 2019, 13, 473-479. [CrossRef] [PubMed]

17. Dreyfus, A.; Wilson, P.; Benschop, J.; Collins-Emerson, J.; Verdugo, C.; Heuer, C. Seroprevalence and herd-level risk factors for seroprevalence of Leptospira spp. in sheep, beef cattle and deer in New Zealand. N. Z. Vet. J. 2018, 66, 302-311. [CrossRef]

18. Alonso-Andicoberry, C.; García-Peña, F.J.; Pereira-Bueno, J.; Costas, E.; Ortega-Mora, L.M. Herd-level risk factors associated with Leptospira spp. seroprevalence in dairy and beef cattle in Spain. Prev. Vet. Med. 2001, 52, 109-117. [CrossRef] 
19. Barrett, D.; Parr, M.; Fagan, J.; Johnson, A.; Tratalos, J.; Lively, F.; Diskin, M.; Kenny, D. Prevalence of Bovine Viral Diarrhoea Virus (BVDV), Bovine Herpes Virus 1 (BHV 1), Leptospirosis and Neosporosis, and associated risk factors in 161 Irish beef herds. BMC Vet. Res. 2018, 14, 8. [CrossRef] [PubMed]

20. Terrazas, S.; Olea, A.; Riedemann, S.; Torres, M. Prevalence of leptospirosis in adults in Chile, 2003. Rev. Chil. Infectol. 2012, 29, 641-647. [CrossRef]

21. Zunino, M.E.; Pizarro, P.R. Leptospirosis: A literature review. Rev. Chil. Infectol. 2007, 24, 220-226. [CrossRef]

22. Picardeau, M. Leptospirosis, neglected among the neglected diseases. PLoS Negl. Trop. Dis. 2018, 171, e0004039. [CrossRef]

23. Munoz-Zanzi, C.; Mason, M.; Encina, C.; Gonzalez, M.; Berg, S. Household characteristics associated with rodent presence and Leptospira infection in rural and urban communities from Southern Chile. Am. J. Trop. Med. Hyg. 2014, 90, 497-506. [CrossRef]

24. ODEPA. Información Regional; ODEPA: Santiago, Chile, 2017.

25. Gadicke, P.; Monti, G. Factors related to the level of occurrence of bovine abortion in Chilean dairy herds. Prev. Vet. Med. 2013, 110, 183-189. [CrossRef]

26. Salgado, M.; Otto, B.; Sandoval, E.; Reinhardt, G.; Boqvist, S. A cross sectional observational study to estimate herd level risk factors for Leptospira spp. serovars in small holder dairy cattle farms in southern Chile. BMC Vet. Res. 2014, 10, 126. [CrossRef] [PubMed]

27. Salgado, M.; Otto, B.; Moroni, M.; Sandoval, E.; Reinhardt, G.; Boqvist, S.; Encina, C.; Munoz-Zanzi, C. Isolation of Leptospira interrogans serovar Hardjoprajitno from a calf with clinical leptospirosis in Chile. BMC Vet. Res. 2015, 11, 66. [CrossRef] [PubMed]

28. Zamora, B.J.; Reidemann, G.S.; Cabezas, O.X. First report of the isolation of Leptospira interrogans serovar hardjo from a bovine uterus in Chile. Av. Cienc. Vet. 1992, 7, 213-214.

29. Schoonman, L.; Swai, E.S. Herd- and animal-level risk factors for bovine leptospirosis in Tanga region of Tanzania. Trop. Anim. Health Prod. 2010, 42, 1565-1572. [CrossRef]

30. Lilenbaum, W.; Souza, G.N. Factors associated with bovine leptospirosis in Rio de Janeiro, Brazil. Res. Vet. Sci. 2003, 75, $249-251$. [CrossRef]

31. Instituto Nacional Estadísticas (INE). Censo Agropecuario; INE: Santiago, Chile, 2017.

32. Anrique, R. Descripción del Chile lechero. In Competitividad de la Producción Lechera Nacional; Anrique, R., Latrille, L., Balochhi, O., Alomar, D., Moreira, V., Smith, R., Pinochet, D., Vargas, G., Eds.; Facultad de Ciencias Agrarias, Universidad Austral de Chile: Valdivia, Chile, 1999; Volume 2, pp. 1-28.

33. Faine, S. Guidelines for the Control of Leptospirosis; World Health Organization: Geneva, Switzerland, 1982.

34. Van De Weyer, L.M.; Hendrick, S.; Rosengren, L.; Waldner, C.L. Leptospirosis in beef herds from western Canada: Serum antibody titers and vaccination practices. Can. Vet. J. 2011, 52, 619-626.

35. Balakrishnan, G.; Roy, P. Comparision of efficacy of two experimental bovine leptospira vaccines under laboratory and field. Vet. Immunol. Immunop. 2014, 159, 11-15. [CrossRef] [PubMed]

36. Lumley, T. Analysis of Complex Survey Samples. J. Stat. Softw. 2004, 9, 1-19. [CrossRef]

37. R Core Team. R: A Language and Enviroment for Stadistical Computing; 3.6.3; R Foundation for Statistical Computing: Vienna, Austria, 2020.

38. Hashimoto, V.Y.; Dias, J.A.; Spohr, K.A.H.; Silva, M.C.P.; Andrade, M.G.B.; Müller, E.E.; Freitas, J.C. Prevalência e fatores de risco associados à Leptospira spp. em rebanhos bovinos da região centro-sul do estado do Paraná. Pesqui. Veterinária Bras. 2012, 32, 99-105. [CrossRef]

39. Parker, J.; Walker, M. Survival of a pathogenic Leptospira serovar in response to combined in vitro $\mathrm{pH}$ and temperature stresses. Vet. Microbiol. 2011, 152, 146-150. [CrossRef]

40. Faine, S.; Adler, B.; Bolin, C.; Perolat, P. Leptospira and Leptospirosis, 2nd ed.; Springer: Melbourne, Australia, 1999.

41. Zamora, J.; Riedemann, S. Wild animals as reservoirs of leptospirosis in Chile. Revision of studies in this country. Arch. Med. Vet. 1999, 31, 151-156.

42. Velásquez, P.C.; Duchens, A.M. Biosecurity practices in commercial dairy farms in Central Chile. Av. Cienc. Vet. 2010, 25. [CrossRef]

43. Olmo, L.; Reichel, M.P.; Nampanya, S.; Khounsy, S.; Wahl, L.C.; Clark, B.A.; Thomson, P.C.; Windsor, P.A.; Bush, R.D. Risk factors for Neospora caninum, bovine viral diarrhoea virus, and Leptospira interrogans serovar Hardjo infection in smallholder cattle and buffalo in Lao PDR. PLoS ONE 2019, 14, e0220335. [CrossRef] [PubMed]

44. Chappel, R.J.; Millar, B.D.; Adler, B.; Hill, J.; Jeffers, M.J.; Jones, R.T.; McCaughan, C.J.; Mead, L.J.; Skilbeck, N.W. Leptospira interrogans serovar hardjo is not a major cause of bovine abortion in Victoria. Aust. Vet. J. 1989, 66, 330-333. [CrossRef] [PubMed]

45. Smith, C.R.; Ketterer, P.J.; McGowan, M.R.; Corney, B.G. A review of laboratory techniques and their use in the diagnosis of Leptospira interrogans serovar hardjo infection in cattle. Aust. Vet. J. 1994, 71, 290-294. [CrossRef] [PubMed]

46. Erregger, E.; Stevenson, M.A.; Beggs, D.S.; Oswin, S.; Jagoe, S.P.; Mansell, P.D.; Pyman, M.F. A cross-sectional pilot study to estimate the prevalence of and risk factors for leptospirosis in South-Western Victorian dairy herds, 2017. Aust. Vet. J. 2020, 98, 417-423. [CrossRef] [PubMed]

47. Marshall, R.B.; Broughton, E.S.; Hellstrom, J.S. Protection of cattle against natural challenge with Leptospira interrogans serovar hardjo using a hardjo-pomona vaccine. N. Z. Vet. J. 1979, 27, 114-116. [CrossRef] 
48. Yupiana, Y.V.E.; Weston, J.; Wilson, P.R.; Collins-Emerson, J.; Benschop, J.; Heuer, C. Shedding and Seroprevalence of Leptospira in Dairy cattle in New Zealand. In Proceedings of the 10th International Leptospirosis Society Conference, Palmerston, New Zealand, 27 November-1 December 2017.

49. Zamora, J.; Riedemann, S.; Frias, M. Porcine leptospirosis. First isolation of Leptospira interrogans serovar tarassovi in Chile. J. Vet. Med. Ser. B 1988, 35, 105-108. [CrossRef] [PubMed]

50. Riedemann, S.; Leal, H.; Zamora, J. The first isolation of Leptospira interrogans serogroup Ballum serovar castellonis in Chile. J. Vet. Med. Ser. B 1986, 33, 393-394. [CrossRef] [PubMed]

51. Bharti, A.; Nally, J.; Ricaldi, J.; Matthias, M.; Diaz, M.; Lovett, M.; Levett, P.; Gilman, R.; Willig, M.; Gotuzzo, E. Leptospirosis: A zoonotic disease of global importance. Lancet Infect. Dis. 2003, 3, 757-771. [CrossRef]

52. Plunkett, A.H.; Graham, T.W.; Famula, T.R.; Oberbauer, A.M. Effect of a monovalent vaccine against Leptospira borgpetersenii serovar Hardjo strain hardjobovis on fertility in Holstein dairy cattle. J. Am. Vet. Med. Assoc. 2013, 242, 1564-1572. [CrossRef] [PubMed]

53. Adler, B. Vaccines Against Leptospirosis. In Leptospira and Leptospirosis; Adler, B., Ed.; Springer: Berlin/Heidelberg, Germany, 2015; Volume 387, pp. 251-272.

54. Leonard, F.C.; Quinn, P.J.; Ellis, W.A.; O'Farrell, K. Association between cessation of leptospiruria in cattle and urinary antibody levels. Res. Vet. Sci. 1993, 55, 195-202. [CrossRef]

55. Ellis, W.A.; JJ, O.B.; Cassells, J. Role of cattle in the maintenance of Leptospira interrogans serotype hardjo infection in Northern Ireland. Vet. Rec. 1981, 108, 555-557. [CrossRef]

56. Gerritsen, M.J.; Koopmans, M.J.; Olyhoek, T. Effect of streptomycin treatment on the shedding of and the serologic responses to Leptospira interrogans serovar hardjo subtype hardjobovis in experimentally infected cows. Vet. Microbiol. 1993, 38, 129-138. [CrossRef]

57. Monahan, A.M.; Callanan, J.J.; Nally, J.E. Host-pathogen interactions in the kidney during chronic leptospirosis. Vet. Pathol. 2009, 46, 792-799. [CrossRef]

58. Levett, P.N. Leptospirosis. Clin. Microbiol. Rev. 2001, 14, 296-326. [CrossRef]

59. Levett, P.N. Usefulness of serologic analysis as a predictor of the infecting serovar in patients with severe leptospirosis. Clin. Infect. Dis. 2003, 36, 447-452. [CrossRef]

60. Blanco, R.M.; dos Santos, L.F.; Galloway, R.L.; Romero, E.C. Is the microagglutination test (MAT) good for predicting the infecting serogroup for leptospirosis in Brazil? Comp. Immunol. Microb. 2016, 44, 34-36. [CrossRef]

61. Ganda, M.R.; Souza, M.A.; Lourencetti, M.P.S.; Ciuffa, A.Z.; Soares, P.M.; Moreira, R.Q.; Lima, A.M.C. Molecular detection of Leptospira spp. in bull semen. Rev. Med. Vet. 2016, 167, 297-301.

62. Hellstrom, J. Studies on Some Aspects of the Epidemiology of Bovine Leptospirosis. Ph.D. Thesis, Massey University, Palmerston North, New Zealand, 1978.

63. Ellis, W.A.; Michna, S.W. Bovine leptospirosis: Infection by the Hebdomadis serogroup and abortion. A herd study. Vet. Rec. 1976, 99, 409-412. [CrossRef] [PubMed] 